\title{
Sexual dysfunctions in a sample of male psychiatric patients compared to medically ill patients
}

\author{
Sameh I. Abdelatti ${ }^{1}$, Reda M. Ismail ${ }^{2}$ and Rania A. Hamed ${ }^{2 *}$
}

\begin{abstract}
Background: Many of the psychiatric disorders and other medical conditions may affect the sexual function of the patients. The present study aims to investigate the frequency of sexual dysfunctions in male psychiatric patients compared to other medically ill patients.

Results: Sexual dysfunction among psychiatric patients (51.2\%) was significantly higher than among other medical patients (21\%). Among the psychiatric patients, those with schizophrenia (75\%) had the highest prevalence rate of sexual dysfunctions. The patients with bipolar disorders, depressive disorders, and anxiety disorders had the following rates respectively: 55\%, 45\%, and 30\%. Among the other medical patients, those with the cardiac diseases (35\%) had the highest prevalence rate of sexual dysfunctions. The patients with hepatic diseases, diabetes, urologic diseases, and respiratory diseases had the following rates respectively: $25 \%, 20 \%, 15 \%$, and $10 \%$. Prolactin level among psychiatric patients was significantly higher than among the other medical patients, while there was no significant difference between the psychiatric and other medical patients regarding total testosterone level.
\end{abstract}

Conclusion: Considering the significant relative frequency of sexual dysfunctions in psychiatric patients, more emphasis is recommended to be placed on the prevention and proper treatment of these disorders.

\section{Background}

Sexuality is more than a mere drive or instinct. Bonding with a sexual partner is a matter of far greater importance than just the gratification of lust [1].

Having pleasurable sexual intercourses plays a major role in marital life satisfaction [2]. Dissatisfaction of the couples in this respect may have the root of various physical, mental, and social problems. Also, many of the medical and psychiatric disorders may affect the sexual function of the patients [3].

The sexual relationship is a complex one, and the factors responsible for problems are not only quite numerous, but in most cases, multiple causes are present. They can be fairly crudely divided into three categories: physical factors, individual psychological factors, and relationship factors [4]. Many sexual problems that are psychological in nature stem from the self- and other-

\footnotetext{
* Correspondence: drrania96@gmail.com

${ }^{2}$ Department of Psychiatry, Faculty of Medicine (for girls), Al-Azhar University, Cairo, Egypt

Full list of author information is available at the end of the article
}

evaluative component of sexual response (hence the common reference to sexual "performance") [5].

Sexual dysfunction is common in people with schizophrenia and other psychotic disorders. It is known to affect all domains of sexual function, including desire, arousal, erection, ejaculation, and orgasm [6], and despite being known to be a major cause of poor quality of life and non-adherence to medication, it is generally underestimated, often neglected, and poorly managed [7]. So far, sexual dysfunction has been largely attributed to the deleterious effect of antipsychotic medication [8], although recent data suggest that it may be a consequence of the disease itself and may also be related to symptom severity [9].

\section{Objectives}

The present study aims to investigate the relative frequency of sexual dysfunctions in male psychiatric patients compared to other medically ill patients and to determine the underlying factors, also, to highlight the role of different psychiatric disorders and other medical 
Table 1 Sociodemographic data among patients of groups I and II

\begin{tabular}{|c|c|c|c|c|}
\hline Sociodemographic data & Group I, N= 80 & Group II, N=100 & Significance test & $P$ value \\
\hline $\begin{array}{l}\text { Age range/years } \\
(\text { mean } \pm \mathrm{SD})\end{array}$ & $\begin{array}{l}29-57 \text { years } \\
(43.3 \pm 7.73)\end{array}$ & $34-58$ years \pm 8.19$)$ & $\begin{array}{l}\text { Student's } t \\
\text { test, } t=0.33\end{array}$ & 0.739 (N.S.) \\
\hline \multicolumn{3}{|l|}{ Educational level } & \multirow{5}{*}{$\begin{array}{l}\text { Chi-square } \\
\text { test, } x^{2}=2.30\end{array}$} & \multirow[t]{5}{*}{0.511 (N.S.) } \\
\hline Illiterate & $10(12.5 \%)$ & $21(21 \%)$ & & \\
\hline Read and write & $22(27.5 \%)$ & $24(24 \%)$ & & \\
\hline Middle education & $35(43.8 \%)$ & $41(41 \%)$ & & \\
\hline High education & $13(16.2 \%)$ & $14(14 \%)$ & & \\
\hline \multicolumn{3}{|l|}{ Occupation } & \multirow{4}{*}{$\begin{array}{l}\text { Chi-square } \\
\text { test, } x^{2}=4.26\end{array}$} & \multirow[t]{4}{*}{0.115 (N.S.) } \\
\hline Jobless & $41(51.25 \%)$ & $37(37 \%)$ & & \\
\hline Manual workers & $29(36.25 \%)$ & $51(51 \%)$ & & \\
\hline Professional workers & $10(12.5 \%)$ & $12(12 \%)$ & & \\
\hline
\end{tabular}

conditions in causing sexual dysfunctions in those patients.

\section{Methods}

\section{Study design}

This study is a descriptive-analytical cross-sectional study.

\section{Site of the study}

The study was carried out on a consecutive series of male psychiatric (group I) and other medical patients (group II) attending outpatient psychiatric clinics of the Abbassia Mental Health Hospital and patients attending cardiac, diabetic, hepatic, urologic, and respiratory outpatient clinics of the Al-Zahraa University Hospital. Both hospitals are in the same catchment area, located in eastern part of Cairo, Egypt.

\section{Time of the study}

The time of the study is during the period from May 2017 to November 2017.

\section{Subjects}

The study was carried out on two groups of male patients: group I included 80 psychiatric patients (20 patients with schizophrenia, 20 patients with bipolar disorders, 20 patients with depressive disorders, and 20 patients with anxiety disorders) (not co-morbid with another medical condition or substance abuse), and group II included 100 other medical patients (20 patients with cardiac diseases, 20 patients with diabetes, 20 patients with hepatic diseases, 20 patients with urologic diseases, and 20 patients with respiratory diseases) (not comorbid with psychiatric disorder or substance abuse).

The inclusion criteria included:

1. Male patients.

2. Ages from 18 to 65 years.

3. Married and cohabitating with their wives.

4. Those who provided written informed consent.

The exclusion criteria included:

1. Female patients.

2. Male patients who are single, widow, divorced, separated, or married but are not cohabitating with their wives.

3. Psychiatric patients with co-morbidity with other medical condition or substance abuse.

4. Medical patients with co-morbidity with psychiatric disorders or substance abuse.

5. Patients receiving other concurrent medications which are known to cause sexual dysfunction on regular basis, those taking phosphodiesterase inhibitors (e.g., sildenafil, tadalafil, and vardenafil) or any other drugs including hormonal preparations which could increase the desire or improve the level of sexual functioning.

6. Male patients whose spouse is suffering from sexual dysfunction (based on the history) due to any cause.

Table 2 Sexual dysfunctions among patients of group I and group ||

\begin{tabular}{|c|c|c|c|c|c|c|c|}
\hline \multirow[t]{2}{*}{ IIEF Questionnaire } & & \multicolumn{2}{|c|}{ Group I, $N=80$} & \multicolumn{2}{|c|}{ Group II, N=100 } & \multirow{2}{*}{$\begin{array}{l}\text { Significance } \\
\text { test }\end{array}$} & \multirow[t]{2}{*}{$P$ value } \\
\hline & & $N$ & $\%$ & $\bar{N}$ & $\%$ & & \\
\hline \multirow[t]{2}{*}{ Sexual function } & Normal & 39 & 48.8 & 79 & 79 & \multirow{2}{*}{$\begin{array}{l}\text { Chi-square test, } \\
x^{2}=18.01\end{array}$} & \multirow[t]{2}{*}{$0.000 *$ (sig.) } \\
\hline & Abnormal & 41 & 51.2 & 21 & 21 & & \\
\hline
\end{tabular}

*Significant difference $(P$ value $<0.05)$ 
Table 3 Sexual dysfunctions among patients of group I (psychiatric patients)

\begin{tabular}{|c|c|c|c|c|c|c|c|c|c|c|c|}
\hline \multicolumn{2}{|c|}{ IIEF Questionnaire } & \multicolumn{10}{|c|}{ Group I (psychiatric patients) } \\
\hline & & \multicolumn{10}{|c|}{$\bar{N}$ (number of patients) $=80$} \\
\hline & & \multicolumn{2}{|c|}{ Schizophrenia, $N=20$} & \multicolumn{2}{|c|}{ Bipolar dis., $N=20$} & \multicolumn{2}{|c|}{ Depressive dis., $N=20$} & \multicolumn{2}{|c|}{ Anxiety dis., $N=20$} & \multirow{2}{*}{$\begin{array}{l}\text { Significance } \\
\text { test (chi- } \\
\text { square test) }\end{array}$} & \multirow[t]{2}{*}{$P$ value } \\
\hline & & $N$ & $\%$ & $N$ & $\%$ & $N$ & $\%$ & $N$ & $\%$ & & \\
\hline \multirow[t]{2}{*}{ Sexual function } & Normal & 5 & 25.0 & 9 & 45.0 & 11 & 55.0 & 14 & 70.0 & \multirow[t]{2}{*}{$x^{2}=8.55$} & \multirow[t]{2}{*}{$0.036^{*}$ (sig } \\
\hline & Abnormal & 15 & 75.0 & 11 & 55.0 & 9 & 45.0 & 6 & 30.0 & & \\
\hline
\end{tabular}

*Significant difference $(P$ value $<0.05)$

7. Patients who were not able to give consent or respond the questions for different reasons including cognitive disorders.

8. Patients who refuse to give written informed consent were also excluded from our study.

\section{Study size}

A convenient sample of patients was selected and subsequently divided into two groups (psychiatric patients and medical patients).

\section{Procedure}

All patients included in the study were subjected to complete history (psychiatric and medical). Diagnosis of psychiatric disorders was done according to the criteria of DSM-5 American Psychiatric Association (2013). Diagnosis of other medical conditions was on the basis of medical history, physical examination, and investigations, wherever needed. Data collection tools were demographic data questionnaire including age, gender, level of education, occupation, type of mental and physical disorders, duration of illness, and compliance with medications.

All patients were subjected to International Index of Erectile Function (IIEF) Questionnaire [10], using the Arabic version [11]. The IIEF Questionnaire was developed to address the need for a self-report measure of both erectile function and sexual function that can be given under guidance of a clinician. The IIEF Questionnaire presents the quality of male sexual function in terms of five domain scores: erectile function, orgasmic function, sexual desire, intercourse satisfaction, and overall satisfaction.

All patients were also subjected to Sexual Behavior Questionnaire (SBQ) [12], using the Arabic version [13]. It is a self-completed gender-specific questionnaire. Eleven questions cover four areas of sexual functioning: desire, arousal, performance, and satisfaction.

A blood sample was taken from every patient for assessment of serum prolactin and total testosterone level.

\section{Statistical methods}

Data collected were reviewed and coded, and the statistical analysis of collected data was done by using the SPSS program (Statistical Package of Social Science; SPSS Inc., Chicago, IL, USA) version 16 for Microsoft Windows.

\section{Results}

There were no statistically significant difference between both groups (psychiatric and other medical patients) as regards the age of the patients, educational level, and occupation $(P$ value $>0.05)$, which means that both groups of patients were matched for sociodemographic data (Table 1).

Sexual dysfunction in the psychiatric patients $(51.2 \%)$ was statistically significantly higher than in the other medical patients $(21 \%)(P$ value $<0.05)$ (Table 2$)$.

Among the patients of group I (psychiatric patients), sexual dysfunction in patients with schizophrenia (75\%) was statistically significantly higher than in patients with bipolar disorders (55\%), depressive disorders (45\%), and anxiety disorders $(30 \%)(P$ value $<0.05)$ (Table 3$)$.

Among the patients of group II (other medical patients), sexual dysfunction in cardiac patients was (35\%), in hepatic patients was (25\%), in diabetic patients was $(20 \%)$, in urologic patients was (15\%), and in respiratory patients was $(10 \%)$, with no statistically significant difference between them $(P$ value $>0.05)($ Table 4$)$.

Table 4 Sexual dysfunctions among patients of group II (other medical patients)

\begin{tabular}{|c|c|c|c|c|c|c|c|c|c|c|c|c|c|}
\hline \multicolumn{2}{|c|}{ IIEF Questionnaire } & \multicolumn{12}{|c|}{ Group II (other medical patients) } \\
\hline & & \multicolumn{12}{|c|}{$N$ (number of patients) $=100$} \\
\hline & & \multicolumn{2}{|c|}{$\begin{array}{l}\text { Cardiac dis., } \\
N=20\end{array}$} & \multicolumn{2}{|c|}{$\begin{array}{l}\text { Diabetes, } N= \\
20\end{array}$} & \multicolumn{2}{|c|}{$\begin{array}{l}\text { Hepatic dis., } \\
N=20\end{array}$} & \multicolumn{2}{|c|}{$\begin{array}{l}\text { Urologic dis., } \\
N=20\end{array}$} & \multicolumn{2}{|c|}{$\begin{array}{l}\text { Respiratory dis., } \\
N=20\end{array}$} & \multirow[t]{2}{*}{ Significance test } & \multirow[t]{2}{*}{$P$ value } \\
\hline & & $N$ & $\%$ & $N$ & $\%$ & $N$ & $\%$ & $N$ & $\%$ & N & $\%$ & & \\
\hline \multirow[t]{2}{*}{ Sexual function } & Normal & 13 & 65 & 16 & 80 & 15 & 75 & 17 & 85 & 18 & 90 & \multirow[t]{2}{*}{ Fisher's exact $=3.46$} & \multirow[t]{2}{*}{0.347 (N.S) } \\
\hline & Abnormal & 7 & 35 & 4 & 20 & 5 & 25 & 3 & 15 & 2 & 10 & & \\
\hline
\end{tabular}


Table 5 Patterns of sexual functions among patients of group I and group ||

\begin{tabular}{|c|c|c|c|c|c|c|c|}
\hline \multirow[t]{2}{*}{ IIEF Questionnaire } & & \multicolumn{2}{|c|}{ Group I, N= 80} & \multicolumn{2}{|c|}{ Group II, N= 100} & \multirow{2}{*}{$\begin{array}{l}\text { Chi- } \\
\text { square } \\
\text { test }\end{array}$} & \multirow[t]{2}{*}{$P$ value } \\
\hline & & $N$ & $\%$ & $N$ & $\%$ & & \\
\hline \multirow[t]{2}{*}{ Erectile function } & Normal & 59 & 73.8 & 80 & 80 & \multirow[t]{2}{*}{$x^{2}=0.99$} & \multirow[t]{2}{*}{0.320 (N.S.) } \\
\hline & Abnormal & 21 & 26.2 & 20 & 20 & & \\
\hline \multirow[t]{2}{*}{ Orgasmic function } & Normal & 39 & 48.8 & 82 & 82 & \multirow[t]{2}{*}{$x^{2}=22.30$} & \multirow[t]{2}{*}{$0.000^{*}$ (sig.) } \\
\hline & Abnormal & 41 & 51.2 & 18 & 18 & & \\
\hline \multirow[t]{2}{*}{ Sexual desire } & Normal & 46 & 57.5 & 88 & 88 & \multirow[t]{2}{*}{$x^{2}=21.73$} & \multirow[t]{2}{*}{$0.000^{*}$ (sig.) } \\
\hline & Abnormal & 34 & 42.5 & 12 & 12 & & \\
\hline \multirow[t]{2}{*}{ Intercourse satisfaction } & Normal & 39 & 48.8 & 79 & 79 & \multirow[t]{2}{*}{$x^{2}=16.71$} & \multirow[t]{2}{*}{$0.000^{*}$ (sig.) } \\
\hline & Abnormal & 41 & 51.2 & 21 & 21 & & \\
\hline \multirow[t]{2}{*}{ Overall sexual satisfaction } & Normal & 39 & 48.8 & 79 & 79 & \multirow[t]{2}{*}{$x^{2}=16.71$} & \multirow[t]{2}{*}{$0.000^{*}$ (sig.) } \\
\hline & Abnormal & 41 & 51.2 & 21 & 21 & & \\
\hline
\end{tabular}

*Significant difference $(P$ value $<0.05)$

Psychiatric patients had a statistically significant higher orgasmic dysfunction, sexual desire dysfunction, intercourse dissatisfaction, and overall sexual dissatisfaction than other medical patients $(P$ value $<0.05)$, with no statistically significant difference between the patients of both groups as regards erectile dysfunction $(P$ value $>$ 0.05) (Table 5).

Among the patients of group I (psychiatric patients), patients with schizophrenia had a statistically significant higher orgasmic dysfunction, intercourse dissatisfaction, and overall sexual dissatisfaction than patients with bipolar disorders, depressive disorders, and anxiety disorders respectively $(P$ value $<0.05)$, with no statistically significant difference between them as regards erectile dysfunction and sexual desire dysfunction ( $P$ value $>$ 0.05) (Table 6).
Among the patients of group II (other medical patients), there was no statistically significant difference between them as regards erectile dysfunction, orgasmic dysfunction, sexual desire dysfunction, intercourse dissatisfaction, and overall sexual dissatisfaction $(P$ value $>$ 0.05) (Table 7).

Psychiatric patients had a statistically significant higher prolactin level than other medical patients $(P$ value < 0.05 ), while there was no statistically significant difference between the patients of both groups as regards total testosterone level $(P$ value $>0.05)$ (Table 8$)$.

Among the patients of group I (psychiatric patients), patients with schizophrenia had a statistically significant higher prolactin level than patients with bipolar disorders, depressive disorders, and anxiety disorders $(P$ value $<$ $0.05)$, with no statistically significant difference between

Table 6 Patterns of sexual functions among patients of group I (psychiatric patients)

\begin{tabular}{|c|c|c|c|c|c|c|c|c|c|c|c|}
\hline \multirow[t]{4}{*}{ IIEF Questionnaire } & & \multicolumn{10}{|c|}{ Group I (psychiatric patients) } \\
\hline & & \multicolumn{10}{|c|}{$N$ (number of patients) $=80$} \\
\hline & & \multicolumn{2}{|c|}{$\begin{array}{l}\text { Schizophrenia, } N= \\
20\end{array}$} & \multicolumn{2}{|c|}{$\begin{array}{l}\text { Bipolar dis., } \\
N=20\end{array}$} & \multicolumn{2}{|c|}{$\begin{array}{l}\text { Depressive dis, } \\
N=20\end{array}$} & \multicolumn{2}{|c|}{$\begin{array}{l}\text { Anxiety dis., } \\
N=20\end{array}$} & \multirow[t]{2}{*}{ Significance test } & \multirow[t]{2}{*}{$P$ value } \\
\hline & & N & $\%$ & N & $\%$ & N & $\%$ & $N$ & $\%$ & & \\
\hline \multirow[t]{2}{*}{ Erectile function } & Normal & 13 & 65.0 & 15 & 75.0 & 14 & 70.0 & 17 & 85.0 & Fisher's exact $=2.26$ & 0.520 (N.S.) \\
\hline & Abnormal & 7 & 35.0 & 5 & 25.0 & 6 & 30.0 & 3 & 15.0 & & \\
\hline \multirow[t]{2}{*}{ Orgasmic function } & Normal & 5 & 25.0 & 9 & 45.0 & 11 & 55.0 & 14 & 70.0 & $x^{2}=8.55$ & $0.036^{*}$ (sig.) \\
\hline & Abnormal & 15 & 75.0 & 11 & 55.0 & 9 & 45.0 & 6 & 30.0 & & \\
\hline \multirow[t]{2}{*}{ Sexual desire } & Normal & 8 & 40.0 & 11 & 55.0 & 12 & 60.0 & 15 & 75.0 & $x^{2}=5.11$ & 0.164 (N.S.) \\
\hline & Abnormal & 12 & 60.0 & 9 & 45.0 & 8 & 40.0 & 5 & 25.0 & & \\
\hline \multirow[t]{2}{*}{ Intercourse satisfaction } & Normal & 5 & 25.0 & 9 & 45.0 & 11 & 55.0 & 14 & 70.0 & $x^{2}=8.55$ & $0.036^{*}$ (sig.) \\
\hline & Abnormal & 15 & 75.0 & 11 & 55.0 & 9 & 45.0 & 6 & 30.0 & & \\
\hline \multirow[t]{2}{*}{ Overall sexual satisfaction } & Normal & 5 & 25.0 & 9 & 45.0 & 11 & 55.0 & 14 & 70.0 & $x^{2}=8.55$ & $0.036^{*}$ (sig.) \\
\hline & Abnormal & 15 & 75.0 & 11 & 55.0 & 9 & 45.0 & 6 & 30.0 & & \\
\hline
\end{tabular}


Table 7 Patterns of sexual functions among patients of group II (other medical patients)

\begin{tabular}{|c|c|c|c|c|c|c|c|c|c|c|c|c|c|}
\hline \multirow[t]{4}{*}{ IIEF Questionnaire } & & \multicolumn{12}{|c|}{ Group II (other medical patients) } \\
\hline & & \multicolumn{12}{|c|}{$N$ (number of patients) $=100$} \\
\hline & & \multicolumn{2}{|c|}{$\begin{array}{l}\text { Cardiac dis., } \\
N=20\end{array}$} & \multicolumn{2}{|c|}{$\begin{array}{l}\text { Diabetes, } \\
N=20\end{array}$} & \multicolumn{2}{|c|}{$\begin{array}{l}\text { Hepatic dis., } \\
N=20\end{array}$} & \multicolumn{2}{|c|}{$\begin{array}{l}\text { Urologic dis., } \\
N=20\end{array}$} & \multicolumn{2}{|c|}{$\begin{array}{l}\text { Respiratory dis., } \\
N=20\end{array}$} & \multirow{2}{*}{$\begin{array}{l}\text { Significance } \\
\text { test (Fisher's } \\
\text { exact) }\end{array}$} & \multirow[t]{2}{*}{$P$ value } \\
\hline & & $N$ & $\%$ & $N$ & $\%$ & $N$ & $\%$ & $N$ & $\%$ & N & $\%$ & & \\
\hline \multirow[t]{2}{*}{ Erectile function } & Normal & 13 & 65 & 16 & 80 & 15 & 75 & 18 & 90 & 18 & 90 & 5.62 & 0.229 (N.S) \\
\hline & Abnormal & 7 & 35 & 4 & 20 & 5 & 25 & 2 & 10 & 2 & 10 & & \\
\hline \multirow[t]{2}{*}{ Orgasmic function } & Normal & 15 & 75 & 16 & 80 & 16 & 80 & 17 & 85 & 18 & 90 & 1.85 & 0.862 (N.S) \\
\hline & Abnormal & 5 & 25 & 4 & 20 & 4 & 20 & 3 & 15 & 2 & 10 & & \\
\hline \multirow[t]{2}{*}{ Sexual desire } & Normal & 17 & 85 & 17 & 85 & 17 & 85 & 18 & 90 & 19 & 95 & 1.51 & 0.824 (N.S) \\
\hline & Abnormal & 3 & 15 & 3 & 15 & 3 & 15 & 2 & 10 & 1 & 5 & & \\
\hline \multirow[t]{2}{*}{ Intercourse satisfaction } & Normal & 13 & 65 & 16 & 80 & 15 & 75 & 17 & 85 & 18 & 90 & 6.17 & 0.186 (N.S) \\
\hline & Abnormal & 7 & 35 & 4 & 20 & 5 & 25 & 3 & 15 & 2 & 10 & & \\
\hline \multirow[t]{2}{*}{ Overall sexual satisfaction } & Normal & 13 & 65 & 16 & 80 & 15 & 75 & 17 & 85 & 18 & 90 & 6.17 & 0.186 (N.S) \\
\hline & Abnormal & 7 & 35 & 4 & 20 & 5 & 25 & 3 & 15 & 2 & 10 & & \\
\hline
\end{tabular}

them as regards total testosterone level $(P$ value $>0.05)$ (Table 9).

Among the patients of group II (other medical patients), there was no statistically significant difference between them as regards prolactin level and total testosterone level ( $P$ value $>0.05)$ (Table 10$)$.

Psychiatric patients with sexual dysfunctions had a statistically significant increase in their ages more than psychiatric patients without sexual dysfunctions (Table 11).

Patients with sexual dysfunctions (either psychiatric or other medical patients) had a statistically significant longer duration of illness than patients without sexual dysfunctions, while compliance with medication was statistically non-significant (Table 12).

Patients with sexual dysfunctions (either psychiatric or other medical patients) had a statistically significant higher prolactin level than patients without sexual dysfunctions, while there was no statistically significant difference between patients with or without sexual dysfunctions as regards total testosterone level (Table 13).

Psychiatric patients with sexual dysfunctions had a statistically significant higher prolactin level than other medical patients with sexual dysfunctions (Table 14), while there was no statistically significant difference between those patients as regards total testosterone level (Table 15).

\section{Discussion}

The aim of the present study was to determine the prevalence rate of sexual dysfunctions in male psychiatric patients in comparison with other medical patients. The results of the study were indicative of higher prevalence rate of sexual dysfunction in the psychiatric patients compared to those in the other medical patients. These results were in accord with the results of other studies, which have reported the prevalence rate of these dysfunctions to be higher in psychiatric patients [14].

The higher rate of sexual dysfunction in psychiatric patients is influenced by different factors such as the type of medical and mental illness together with the drugs used, marital and relationship problems between the patients and their spouses, and cultural and social issues [15].

As the causes of sexual dysfunctions are multifactorial and due to using different tools to measure these dysfunctions, the rate of these dysfunctions in various studies has been reported from 17 to 80\% [16]. Moreover, other studies exert an increase in the prevalence rate of

Table 8 Hormonal levels among patients of group I and group ||

\begin{tabular}{|c|c|c|c|c|c|c|c|}
\hline \multirow[t]{2}{*}{ Hormonal level } & & \multicolumn{2}{|c|}{ Group I, N=80 } & \multicolumn{2}{|c|}{ Group $\|, N=100$} & \multirow{2}{*}{$\begin{array}{l}\text { Chi- } \\
\text { square } \\
\text { test }\end{array}$} & \multirow[t]{2}{*}{$P$ value } \\
\hline & & $N$ & $\%$ & $N$ & $\%$ & & \\
\hline \multirow[t]{2}{*}{ Prolactin } & Normal & 60 & 75.0 & 97 & 97 & $x^{2}=19.30$ & $0.000^{*}$ (sig.) \\
\hline & High & 20 & 25.0 & 3 & 3 & & \\
\hline \multirow[t]{2}{*}{ Total testosterone } & Normal & 78 & 97.5 & 99 & 99 & $x^{2}=00.61$ & 0.434 (N.S.) \\
\hline & Low & 2 & 2.5 & 1 & 1 & & \\
\hline
\end{tabular}


Table 9 Hormonal levels among patients of group I (psychiatric patients)

\begin{tabular}{|c|c|c|c|c|c|c|c|c|c|c|c|}
\hline \multirow[t]{4}{*}{ Hormonal level } & & \multicolumn{10}{|c|}{ Group I (psychiatric patients) } \\
\hline & & \multicolumn{10}{|c|}{$N$ (number of patients) $=80$} \\
\hline & & \multicolumn{2}{|c|}{ Schizophrenia, $N=20$} & \multicolumn{2}{|c|}{ Bipolar dis., $N=20$} & \multicolumn{2}{|c|}{ Depressive dis., $N=20$} & \multicolumn{2}{|c|}{ Anxiety dis., $N=20$} & \multirow{2}{*}{$\begin{array}{l}\text { Significance } \\
\text { test (chi- } \\
\text { square test) }\end{array}$} & \multirow[t]{2}{*}{$P$ value } \\
\hline & & $N$ & $\%$ & $N$ & $\%$ & $N$ & $\%$ & $N$ & $\%$ & & \\
\hline \multirow[t]{2}{*}{ Prolactin } & Normal & 11 & 55.0 & 15 & 75.0 & 15 & 75.0 & 19 & 95.0 & $x^{2}=8.53$ & $0.036^{*}$ (sig.) \\
\hline & High & 9 & 45.0 & 5 & 25.0 & 5 & 25.0 & 1 & 5.0 & & \\
\hline \multirow[t]{2}{*}{ Total testosterone } & Normal & 19 & 95.0 & 19 & 95.0 & 20 & 100 & 20 & 100 & $x^{2}=2.05$ & 0.561 (N.S.) \\
\hline & Low & 1 & 5.0 & 1 & 5.0 & 0 & 0.0 & 0 & 0.0 & & \\
\hline
\end{tabular}

*Significant difference $(P$ value $<0.05)$

mental disorders in those patients with sexual dysfunction [17].

In our study, the results revealed that the mean age (in years) of $47.26 \pm 7.41$ and $45.09 \pm 9.22$ had the highest rate of sexual dysfunction in psychiatric and other medical patients respectively. This was in accordance with other studies that have reported sexual dysfunction in the patients between 35 and 64 years old to be higher than in the patients between 18 and 34 years old [16]. This was consistent with other Egyptian studies: Habeeb who found that the sexual function is negatively correlated with age [18] and Mohammed who found that sexual function in patients with paranoid schizophrenia is affected negatively by sociodemographic factor (aging) [13].

It is noteworthy to mention that the patients included in our study were selected from the Abbassia Mental Health Hospital and Al-Zahraa University Hospital. Both hospitals offer their services to the patients of low socioeconomic standards on a low price basis; this may reflect the high prevalence of patients with low education and low occupation in this study.

In this study, the results showed that psychiatric and other medical patients with sexual dysfunction had a statistically significant longer duration of illness than psychiatric and other medical patients without sexual dysfunctions $(P$ value $<0.05)$. This finding is in agreement with Schover who stated that the patients who had chronic and long duration of illness often had difficulties in sexual functioning [17]. Egyptian studies were also supporting this finding:
Mohammed found that sexual function in patients with paranoid schizophrenia is affected negatively by long duration of illness [13], and Hashem et al. reported that long duration of schizophrenia may lead to sexual dysfunctions among schizophrenics [19].

In this study, we found that sexual dysfunction was significantly higher in the psychiatric patients $(51.2 \%)$ than in the other medical patients $(21 \%)(P$ value $<0.05)$. This finding is confirmed by other studies, where Bobes et al. reported that the prevalence of sexual dysfunction among psychiatric patients is higher in comparison to non-psychiatric patients and the general population [20]. Also, Van Lankveld and Grotjohann stated that psychiatric patients have significantly more sexual dysfunction than non-psychiatric patients and also more than in the general population [21].

In this work, the results revealed that among the psychiatric patients, those with schizophrenia $(75 \%)$ had the highest prevalence rate of sexual dysfunctions. The patients with bipolar disorders, depressive disorders, and anxiety disorders had the following rates respectively. This result comes in accordance with the result of the study done by Fanta $\mathrm{T}$ et al. who reported that the overall sexual dysfunction among male schizophrenics was 84.5\% [22]. Also, Smith et al. reported that $45 \%$ of schizophrenics taking conventional antipsychotic medications have sexual dysfunction [12].

These findings are supported with the findings of Macdonald et al. who found that at least one sexual

Table 10 Hormonal levels among patients of group II (other medical patients)

\begin{tabular}{|c|c|c|c|c|c|c|c|c|c|c|c|c|c|}
\hline \multirow[t]{4}{*}{ Hormonal level } & & \multicolumn{12}{|c|}{ Group II (other medical patients) } \\
\hline & & \multicolumn{12}{|c|}{$N$ (number of patients) $=100$} \\
\hline & & \multicolumn{2}{|c|}{$\begin{array}{l}\text { Cardiac dis., } N= \\
20\end{array}$} & \multicolumn{2}{|c|}{$\begin{array}{l}\text { Diabetes, } N= \\
20\end{array}$} & \multicolumn{2}{|c|}{$\begin{array}{l}\text { Hepatic dis., } N= \\
20\end{array}$} & \multicolumn{2}{|c|}{$\begin{array}{l}\text { Urologic dis., } N= \\
20\end{array}$} & \multicolumn{2}{|c|}{$\begin{array}{l}\text { Respiratory dis., } N= \\
20\end{array}$} & \multirow{2}{*}{$\begin{array}{l}\text { Significance } \\
\text { test (chi- } \\
\text { square test) }\end{array}$} & \multirow[t]{2}{*}{$P$ value } \\
\hline & & $N$ & $\%$ & $N$ & $\%$ & N & $\%$ & $N$ & $\%$ & $N$ & $\%$ & & \\
\hline \multirow[t]{2}{*}{ Prolactin } & Normal & 18 & 90 & 20 & 100 & 19 & 95 & 20 & 100 & 20 & 100 & \multirow[t]{2}{*}{$x^{2}=5.50$} & \multirow[t]{2}{*}{0.347 (N.S) } \\
\hline & High & 2 & 10 & 0 & 0 & 1 & 5 & 0 & 0 & 0 & 0 & & \\
\hline \multirow[t]{2}{*}{ Total testosterone } & Normal & 20 & 100 & 20 & 100 & 19 & 95 & 20 & 100 & 20 & 100 & \multirow[t]{2}{*}{$x^{2}=4.04$} & \multirow[t]{2}{*}{0.347 (N.S) } \\
\hline & Low & 0 & 0 & 0 & 0 & 1 & 5 & 0 & 0 & 0 & 0 & & \\
\hline
\end{tabular}


Table 11 Correlation between age of patients and clinical scales (IIEF and SBQ) among patients of group I (psychiatric patients)

\begin{tabular}{|c|c|c|c|c|}
\hline \multirow{3}{*}{$\begin{array}{l}\text { Age of } \\
\text { patients }\end{array}$} & \multicolumn{2}{|c|}{ Group I (psychiatric patients) } & \multirow{3}{*}{$\begin{array}{l}\text { Significance } \\
\text { test } \\
\text { (Student's } t \\
\text { test) }\end{array}$} & \multirow{3}{*}{$\begin{array}{l}P \\
\text { value }\end{array}$} \\
\hline & \multicolumn{2}{|c|}{$N$ (number of patients) $=80$} & & \\
\hline & $\begin{array}{l}\text { Psychiatric } \\
\text { patients with } \\
\text { sexual } \\
\text { dysfunction ( } N= \\
41 \text { ) }\end{array}$ & $\begin{array}{l}\text { Psychiatric patients } \\
\text { without sexual } \\
\text { dysfunction }(N= \\
\text { 39) }\end{array}$ & & \\
\hline $\begin{array}{l}\text { Age/ } \\
\text { years } \\
\text { (mean } \pm \\
\text { SD) }\end{array}$ & $47.26 \pm 7.41$ & $39.41 \pm 6.00$ & $t=5.03$ & $\begin{array}{l}0.000^{*} \\
\text { (sig.) }\end{array}$ \\
\hline
\end{tabular}

*Significant difference $(P$ value $<0.05)$

dysfunction was reported by $82 \%$ of male schizophrenic patients [23].

The previous studies confirmed that sexual dysfunction is very common in patients with schizophrenia. This reflects another aspect of the poor quality of life led by many people with schizophrenia that should be addressed.

The high prevalence of sexual dysfunctions in patients with schizophrenia was proved by several studies to be the cause of sexual side effects of using antipsychotics in those patients. In this respect, Mccreadie found that depot antipsychotic treatment resulted in sexual dysfunction [23]. Also, Atmaca et al. concluded that sexual dysfunction is an important problem in schizophrenics even with novel antipsychotics [24]. In a study done by Kockott and Pfeiffer to study sexual disorder in nonacute psychiatric patients, they found that schizophrenic patients on neuroleptic medications are most frequently affected, whereas schizophrenic patients not in medications have fewer dysfunctions [25].

The results of our study revealed that $60 \%$ of patients with schizophrenia had sexual desire dysfunction. This was consistent with the study done by [22] who reported that $62 \%$ of male chronic schizophrenics have reduced libido. The "disease-related" sexual desire reduction might be induced by an unknown underlying process, the patients' psychotic symptoms, or as part of the general loss of initiative and activity level (i.e., negative symptoms) [26].
Regarding the ejaculatory function, we found that $75 \%$ of patients with schizophrenia had ejaculatory dysfunction. This was consistent with the study of [22] who reported that $86 \%$ of male chronic schizophrenics had ejaculatory dysfunction. This emphasizes that direct questioning about sexual functioning including sexual side effects is necessary to avoid underestimating their frequency among the psychiatric patients.

In the present study, we found that $45 \%$ of patients with depressive disorders had sexual dysfunctions. This was in agreement with the study done by [27] who reported that $54 \%$ of depressed male patients have sexual dysfunction. Our results showed that $40 \%$ of patients with depressive disorders have sexual desire dysfunction. In this respect [27], reported that $37.03 \%$ of depressed male patients have lack of sexual desire. Also, the results of our study revealed that $30 \%$ of patients with depressive disorders had erectile dysfunction. This was consistent with the study done by [27] who reported that $22.22 \%$ of depressed male patients have lack of erection. This may lead us to advice the psychiatrists to bear this in mind, and they should ask about the sexual power before starting treatment and during follow-up and to reassure the patients if there is any problem.

In the present study, we found that $55 \%$ of patients with bipolar disorders had sexual dysfunctions. This comes in accordance with [28], who reported that the co-administration of benzodiazepines and lithium resulted in significantly higher rates of sexual dysfunction (49\%) in bipolar patients. Additionally, in our study, the results showed that $30 \%$ of patients with anxiety disorders had ejaculatory dysfunctions. In this respect, [29] concluded that anxiety or fear of failing to meet a partner's expectations is one of the most common causes of premature ejaculation.

In the present study, we found that among the other medical patients, those with the cardiac diseases (35\%) had the highest prevalence rate of sexual dysfunctions. The patients with hepatic diseases, diabetes, urologic diseases, and respiratory diseases had the following rates respectively. This was confirmed by Ahmadzadeh and Shahin who concluded that cardiac patients (37.1\%) had

Table 12 Comparison of duration of illness and compliance with medications among psychiatric patients with sexual dysfunctions and other medical patients with sexual dysfunctions

\begin{tabular}{|c|c|c|c|c|c|c|}
\hline \multirow{2}{*}{$\begin{array}{l}\text { Duration of illness and } \\
\text { compliance with } \\
\text { medications }\end{array}$} & \multicolumn{4}{|c|}{ Patients with sexual dysfunctions } & \multirow[t]{2}{*}{ Significance test } & \multirow[t]{2}{*}{$P$ value } \\
\hline & \multicolumn{2}{|c|}{$\begin{array}{l}\text { Psychiatric patients with } \\
\text { sexual dysfunction }(N=41)\end{array}$} & \multicolumn{2}{|c|}{$\begin{array}{l}\text { Other medical patients } \\
\text { with sexual dysfunction } \\
(N=21)\end{array}$} & & \\
\hline Duration/years (mean \pm SD) & \multicolumn{2}{|c|}{$15.68 \pm 8.25$} & \multicolumn{2}{|c|}{$11.23 \pm 3.16$} & $t=2.37$ & $0.021 *$ (sig.) \\
\hline Compliant & 39 & $95.1 \%$ & 20 & $95.2 \%$ & Chi-square test, $x^{2}=0.00$ & 0.984 (N.S.) \\
\hline Non-compliant & 2 & $4.9 \%$ & 1 & $4.8 \%$ & & \\
\hline
\end{tabular}

*Significant difference $(P$ value $<0.05)$ 
Table 13 Comparison of hormonal levels among psychiatric patients with sexual dysfunctions and other medical patients with sexual dysfunctions

\begin{tabular}{|c|c|c|c|c|c|c|c|}
\hline \multirow[t]{3}{*}{ Hormonal level } & & \multicolumn{4}{|c|}{ Patients with sexual dysfunctions } & \multirow{3}{*}{$\begin{array}{l}\text { Significance } \\
\text { test (chi- } \\
\text { square test) }\end{array}$} & \multirow[t]{3}{*}{$P$ value } \\
\hline & & \multicolumn{2}{|c|}{$\begin{array}{l}\text { Psychiatric patients with sexual dysfunction } \\
(N=41)\end{array}$} & \multicolumn{2}{|c|}{$\begin{array}{l}\text { Other medical patients with sexual dysfunction } \\
(N=21)\end{array}$} & & \\
\hline & & $\bar{N}$ & $\%$ & $N$ & $\%$ & & \\
\hline \multirow[t]{2}{*}{ Prolactin level } & Normal & 24 & 58.5 & 19 & 90.5 & \multirow[t]{2}{*}{$x^{2}=6.66$} & \multirow[t]{2}{*}{$0.010^{*}$ (sig. } \\
\hline & High & 17 & 41.5 & 2 & 9.5 & & \\
\hline \multirow[t]{2}{*}{ Total testosterone } & Normal & 39 & 95.1 & 20 & 95.2 & \multirow[t]{2}{*}{$x^{2}=0.00$} & \multirow[t]{2}{*}{0.984 (N.S.) } \\
\hline & Low & 2 & 4.9 & 1 & 4.8 & & \\
\hline
\end{tabular}

*Significant difference $(P$ value $<0.05)$

the highest prevalence rate of sexual dysfunction among the patients in non-psychiatric wards [30].

Our study revealed that $35 \%$ of patients with cardiac diseases had erectile dysfunction. Consistently, data from several studies involving patients with cardiac disease have shown a high prevalence, $42-75 \%$, of erectile dysfunction in this patient population [31]. Also, the results showed that $20 \%$ of diabetic patients had erectile dysfunction. This was in accordance with [32] who stated that the prevalence of erectile dysfunction among diabetic patients is $20-65 \%$. Moreover, our results showed that $25 \%$ of patients with hepatic diseases had sexual dysfunctions. In this respect, we should mention that liver has a major role in sex hormone metabolism. In the present study, we found that $15 \%$ of patients with urologic diseases had sexual dysfunctions. This comes in accordance with the study done by [33] who stated that a common problem that remains difficult to diagnose and treat in patients with chronic renal failure is sexual dysfunction. Our study showed that $10 \%$ of patients with respiratory diseases had sexual dysfunction. Also, [34] found that $21 \%$ of men with COPD had erectile dysfunction. In fact, any chronic illness may be associated with sexual dysfunction.

In the present study, the results revealed that psychiatric patients with sexual dysfunction had statistically significant higher prolactin level than psychiatric patients

Table 14 Comparison of total testosterone level among psychiatric patients with sexual dysfunctions and other medical patients with sexual dysfunctions

\begin{tabular}{|c|c|c|c|c|c|c|c|}
\hline \multirow[t]{3}{*}{ Hormonal leve } & & \multicolumn{4}{|c|}{$\begin{array}{l}\text { Patients with sexual } \\
\text { dysfunctions }\end{array}$} & \multirow{3}{*}{$\begin{array}{l}\text { Significance } \\
\text { test (chi- } \\
\text { square test) }\end{array}$} & \multirow[t]{3}{*}{$\begin{array}{l}P \\
\text { value }\end{array}$} \\
\hline & & \multicolumn{2}{|c|}{$\begin{array}{l}\text { Psychiatric } \\
\text { patients } \\
\text { with sexual } \\
\text { dysfunction } \\
(N=41)\end{array}$} & \multicolumn{2}{|c|}{$\begin{array}{l}\text { Other } \\
\text { medical } \\
\text { patients } \\
\text { with sexual } \\
\text { dysfunction } \\
(N=21)\end{array}$} & & \\
\hline & & $N$ & $\%$ & $N$ & $\%$ & & \\
\hline \multirow{2}{*}{$\begin{array}{l}\text { Total } \\
\text { testosterone }\end{array}$} & Normal & 39 & 95.1 & 20 & 95.2 & \multirow[t]{2}{*}{$x^{2}=0.00$} & \multirow{2}{*}{$\begin{array}{l}0.984 \\
\text { (N.S.) }\end{array}$} \\
\hline & Low & 2 & 4.9 & 1 & 4.8 & & \\
\hline
\end{tabular}

without sexual dysfunction. Also, we found that patients with schizophrenia (higher rate of sexual dysfunction) had statistically significant higher prolactin level than other psychiatric patients. These findings can prove that elevated prolactin level may cause sexual dysfunction. This is consistent with the study done by Bruno who reported that hyperprolactinemic patients reported significant degree of sexual dysfunction [35].Hyperprolactinemic patients reported significant degree of sexual desire dysfunction, orgasm dysfunction, sexual satisfaction dysfunction, and low frequency of sexual intercourses which is supported with that hyperprolactinemia caused hypogonadism with suppressed LH and FSH levels and low testosterone levels.

In this study, we found no significant difference between psychiatric and other medical patients and between patients with and without sexual dysfunction as regards total testosterone level. This is contrary to [36] who reported that a component of the increased risk conferred by erectile dysfunction could be testosterone deficiency.

\section{Limitations}

This study was a cross-sectional one; the nature of this study limits the possibility to explore the cause and effect relationship between sexual dysfunctions and

Table 15 Comparison of prolactin level among psychiatric patients with sexual dysfunctions and other medical patients with sexual dysfunctions

\begin{tabular}{|c|c|c|c|c|c|c|c|}
\hline \multirow{3}{*}{\multicolumn{2}{|c|}{ Hormonal level }} & \multicolumn{4}{|c|}{$\begin{array}{l}\text { Patients with sexual } \\
\text { dysfunctions }\end{array}$} & \multirow{3}{*}{$\begin{array}{l}\text { Significance } \\
\text { test (chi- } \\
\text { square test) }\end{array}$} & \multirow[t]{3}{*}{$P$ value } \\
\hline & & \multicolumn{2}{|c|}{$\begin{array}{l}\text { Psychiatric } \\
\text { patients } \\
\text { with sexual } \\
\text { dysfunction } \\
(N=41)\end{array}$} & \multicolumn{2}{|c|}{$\begin{array}{l}\text { Other } \\
\text { medical } \\
\text { patients } \\
\text { with sexual } \\
\text { dysfunction } \\
(N=21)\end{array}$} & & \\
\hline & & $\bar{N}$ & $\%$ & $\bar{N}$ & $\%$ & & \\
\hline \multirow{2}{*}{$\begin{array}{l}\text { Prolactin } \\
\text { level }\end{array}$} & Normal & 24 & 58.5 & 19 & 90.5 & \multirow[t]{2}{*}{$x^{2}=6.66$} & \multirow{2}{*}{$\begin{array}{l}0.010^{*} \\
\text { (sig.) }\end{array}$} \\
\hline & High & 17 & 41.5 & 2 & 9.5 & & \\
\hline
\end{tabular}

*Significant difference $(P$ value $<0.05)$ 
psychiatric diagnosis. Also, some subjects did not complete the International Index for Erectile Function (IIEF) Questionnaire and Sexual Behavior Questionnaire (SBQ) because of being considered as taboo and shies away from providing any information about sexual functioning.

\section{Conclusion}

The persistence of sexual problems has significant negative impact on patient's satisfaction and adherence with the treatment, quality of life, and partnership. Routine assessment of sexual functioning needs to be integrated into ongoing care to identify and address problems early. If sexual dysfunction is ignored, it may maintain the psychiatric disorder, compromise treatment outcome, and lead to non-adherence.

\section{Abbreviations}

IIEF: International Index of Erectile Function; SBQ: Sexual Behavior Questionnaire; SPSS: Statistical Package of Social Science

\section{Acknowledgements}

The authors would like to express their gratitude to all participants of this study.

\section{Authors' contributions}

SIA collected the patients' data and applied the scales. RMI designed the study. RAH analyzed and interpreted the patient data. All authors read and approved the final manuscript.

\section{Funding}

None

\section{Availability of data and materials}

Not applicable.

\section{Ethics approval and consent to participate}

Patients were included in this study after giving written informed consent after explaining the nature and the aim of the study and the confidentiality of informations. Also, ethical issues and anonymity of patients' names were taken in consideration. The study was done consistent with good clinical practice and the Declaration of Helsinki and World Health Organization guidelines. The reference number is not available.

\section{Consent for publication}

Not applicable.

\section{Competing interests}

The authors declare that they have no competing interests.

\section{Author details}

${ }^{1}$ Abbasia Mental Health Hospital, Cairo, Egypt. ${ }^{2}$ Department of Psychiatry, Faculty of Medicine (for girls), Al-Azhar University, Cairo, Egypt.

Received: 9 February 2020 Accepted: 14 February 2020

Published online: 17 April 2020

\section{References}

1. Steven A, Price J (2000) Evolutionary psychiatry; a new beginning, 2nd edn. Routledge, London

2. Rahmani A, Merghati E, AllahGholi L (2012) Sexual satisfaction and its relation to marital happiness in Iranians. Iran J Publ Heal 38:77-82

3. Dunn KM, Croft PR, Halkett Gl (1999) Association of sexual problems with social, psychological and physical problems in men and women. Epidemiol Comm Heal 53:144-148
4. Bancroft JHJ (1989) Human sexuality and its problems, 2nd edn. Churchill Livingstone, Edinburgh

5. Rowland DL, Incrocci L (2008) Handbook of sexual and gender identity disorders. Hoboken, N.J.: John Wiley \& Sons, p.80.

6. Howes OD, Wheeler MJ, Pilowsky LS, Landau S, Murray RM, Smith S (2007) Sexual function and gonadal hormones in patients taking antipsychotic treatment for schizophrenia or schizoaffective disorder. J Clin Psych 68:361367

7. Montejo AL, Majadas S, Rico-Villademoros F, Lorca G, De La Gandara J, Franco M (2010) Frequency of sexual dysfunction in patients with a psychotic disorder receiving antipsychotics. J Sex Med 7:3404-3413

8. Westheide J, Cohen S, Bender S, Cooper-Mahkorn D, Erfurth A, Gastpar M (2007) Sexual dysfunction in psychiatric inpatients the role of antipsychotic medication. Pharmacopsych 40:140-145

9. Malik P, Kemmler G, Hummer M, Riecher-Rössler A, Kahn RS, Fleischhacker WW (2015) Sexual dysfunction in first-episode schizophrenia patients: results from European first episode schizophrenia trial. J Clin Psychopharmacol 31: 274-280

10. Rosen R, Riley A, Wagner G, Osterloh I, Kirkpatrick J, Mishra A (1997) The international index of erectile function (IIEF): a multidimensional scale for assessment of erectile dysfunction. Urol 49:822-830

11. Shamloul R, Ghanem H, Abou-zeid A (2004) Validity of the Arabic version of the sexual health inventory for men among Egyptians. Int J Impot Res 16(5): 452-455

12. Macdonald S, Halliday J, Macewan T, Sharkey V, Farrington S, Wall S, Mccreadie RG (2003) Nithsdale Schizophrenia Surveys 24: sexual dysfunction, case-control study. Br J Psych 182:50-56

13. Mohammed H. (2005): A study of sexual aspects in a sample of male schizophrenic patients. M.Sc Thesis, Faculty of medicine, Cairo University, supervised by Prof. Abdel Hamid Hashem, Prof. Tarek Abd El-Gawad and Prof. Mohammed Arafa; 2005

14. Quinn C, Browne G (2009) Sexuality of people living with a mental illness. Int J Ment Health Nurs 18:195-203

15. Qnek KF, Salam AA, Chun CB (2010) Prevalence of sexual problems and its association with social psychological and physical factors among men in Malaysian population. J Sex Med 5:70-76

16. Perlman CM, Martial L, Hirdes JP, Curtin-Telegdi N, Pérez E, Rabinowitz T (2007) Prevalence and predictors of sexual dysfunction psychiatric inpatients. Psychosom 48:309-318

17. Schover LR (2016) Sexual problems in chronic illness. Principles and practice of sex therapy, 3rd edn. Guilford, New York, pp 398-422

18. Habeeb BF. Sexual dysfunction and paraphilias of general medical hospital male in-patients. M.Sc Thesis, Faculty of medicine, CairoUniversity, supervised by Prof. Said Abdel Azim, Prof. Kamal Zaki and Prof. Ahmed Abdel Latif; 2000

19. Hashem AH, Abd El-Gawad T, Ezzat M, Assal A, Goueily T, El Rakhawy M (2006) A comparative study of sexual function in paranoid versus nonparanoid schizophrenic patients and its relation serum prolactin level. Curr Psych 13(2):206-225.

20. Bobes J, Gonzalez MP, Bascaran MT (2010) Evaluating changes in sexual functioning in depressed patients sensitivity to change of the CSFQ. J Sex Mar Thera 28:93-103

21. Van Lankveld J, Grotjohann Y (2016) Psychiatry comorbidity in hetero sexual couples with sexual dysfunction assessed with composite international diagnostic interview. Arch of Sex Behav 29(5):479-498

22. Fanta T, Haile K, Abebaw D, Assefa D, Hibdye G (2017) Assessment of sexual dysfunction and associated factors among patients with schizophrenia in Ethiopia. BMC Psychiatry 18:158. https://doi.org/10.1186/s12888-018-1738-3.

23. Diederik ET, Peter $\mathrm{NH}$, Cees JS (2017) Tardive dyskinesia in schizophrenia is associated with prolactin-related sexual disturbance. Neuropsychopharmaco 31:1832-1837

24. Atmaca M, Kuloglu M, Tezcan E (2014) New atypical antipsychotic: quetiapine-induced sexual dysfunctions. Int J Impot Res 2:201-203.

25. Kockott G, Pfeiffer W (1996) Sexual disorder in non acute psychiatric outpatients. Compr Psych 37(1):56-61

26. De Boer MK, Wiersma D, Bous J, Sytema S, Van der Moolen AE (2006) A randomized open-label comparison of the impact of aripiprazole versus risperidone on sexual functioning (RAS study). J Clin Psychopharmacol 31: 523-525

27. Ahmed MM, Ezz E-DS (1992) Sexual dysfunction in patients with major depression. Egy J Psych 15:2 
28. Kaplan HS (1988) Anxiety and sexual dysfunction. J Clin Psych 49:21-25

29. Williams W (1984) Secondary premature ejaculation. Aust NZJ Psych 18:333-340

30. Ahmadzadeh G, Shahin A (2015) Sexual dysfunctions in the patients hospitalized in psychiatric wards compared to other specialized wards in Isfahan, Iran. Adv Biomed Res 4:225

31. Kloner RA (2014) Assessment of cardiovascular risk in patients with erectile dysfunction: focus on the diabetic patient. Endocrine 23:125-129

32. Shiri R (2003) Prevalence and severity of erectile dysfunction in 50 to 75 year old Finnish men. J Urol 170:2342-2344

33. Procci WR, Goldstein DD, Adelstein J, Massry SG (1981) Sexual dysfunction in the male patient with uremia. A reappraisal. Kidney Int 19(2):317-323.

34. Kahraman H, Sen B, Koksal N, Kilinç M, Resim S (2013) Erectile dysfunction and sex hormone changes in chronic obstructive pulmonary disease patients. Multidiscip Respir Med 8:66

35. Bruno R (2016) Relationship between the symptomatology and neuropsychology of schizophrenia: three, five, eleven, or a greater number of valid syndromes? Fam Relat 55:146

36. Fung MM, Bettencout R, Barret-Connor E (2014) Heart disease risk factors predict erectile dysfunction 25 years later the rancho Bernardo study. J Am Coll Cardiol 43:1405-1411

\section{Publisher's Note}

Springer Nature remains neutral with regard to jurisdictional claims in published maps and institutional affiliations.

\section{Submit your manuscript to a SpringerOpen ${ }^{\circ}$ journal and benefit from:}

- Convenient online submission

- Rigorous peer review

- Open access: articles freely available online

- High visibility within the field

- Retaining the copyright to your article 